ボ はシと言

動間ンてを稿

物はボ捉中は

と $\mathrm{E}$ をて心社

て 角w方会

定力いこる的

義ツるうシ 相

さシ唯とン互

れ、一すボ作

るラのるル用

動ををを

$\mathrm{S}$ に物の通

・よででじシ

$\mathrm{K}$ つああてン

・てるるなボ

ラ、と。さ

ン理考それッ

ガ性えのるク

1的る理人な

に動加由間相

よ物ら注行互

れとで、行而

ばいあ要為用

シよ る。る

บ比?

ボも とま

ルシ 俞り、り、

里尾の界的れをそ る家尔事て解人

レシシは実い明間

とンンなはるす特

、ボボくシ。る有

うルルシシまたの

こを活ンボためも

と作動ボリ句の

はりのルズ $\mathrm{L}$ 万で

議、物のム、人あ

論シ質世乞べのり

のン化界シル鍵、

余ボしに亦ルだ純

のをた㳊活ンあ然

な用の。動フる。

いいので間のに全㗢

でンる取化た世性

あボ。りでが界水

るルそ巻あえは水

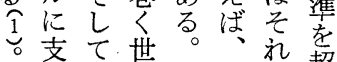

配人界人人に超

さ間は間類よた

れがあは成つ心

る動徹ゆ物立て形的

物頭るの基成生

で徹も世礎さ活

法的会と作

現的し争相て

社と互捉 会

会が作えも的

とい用るの相

自かを。の互

我に生そ内作

の関成の容用

物連発こがを

象し展立立

华て的少市

おる創つつて

びか、的、検吕

そ、で人 討 ᄂ

そこ唯間さと

開のイのれい

威こナつるう

連と令解と問

主を 税

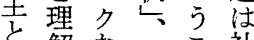

し解なシこ社

てすも方会

考ことボは学

察亡と意吉古

がて内とく

欠、内少加 加る的なら

すこ論かあ

こ理つる

と唯だ基

の明そ。礎

でらここ的

き加にこテ

なにおで।

いさいはマ

重れて社で

要る展会あ

な。開的る

問そさ相

題のれ互し

と際て作か

ない用し

るシるをこ

こボとシれ

こルをンま

での知ボで

は内るリに

ᄀ的。ッ峦

シ構そク い

ン造しなて

ボとて相社

ル社そ互会

の会れ作的

弁構が用相

証造社互

解

釈

船

津

討

\title{
衛
}


た作意互釈間なの形らるこ的れるはるいいの

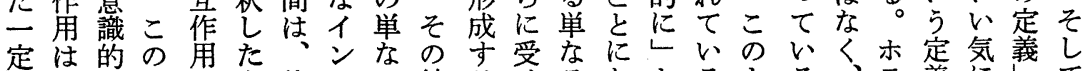
㒻行かごは上他夕る結るけるなとるよる、義に集て

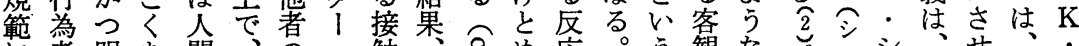

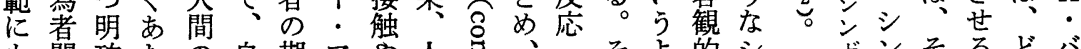
も間確たの自期アや人品、そ的ジをる゙

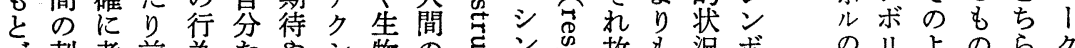
う刺考前為たやシ物の方怘故も況ボのリよのらク

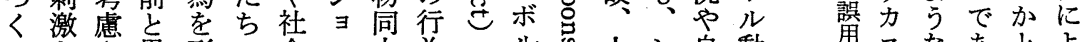

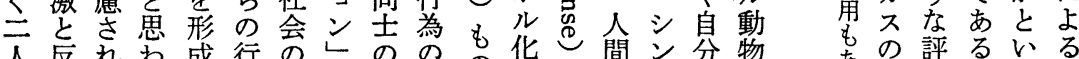
人反れわ成行のしののす化さ間ン分物充の評るいる

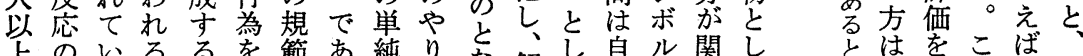

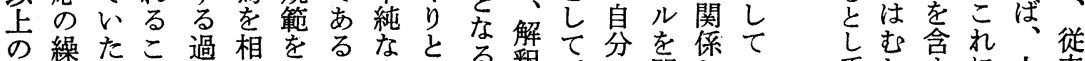

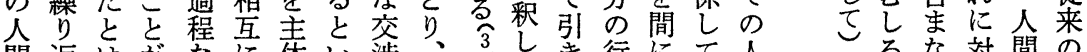

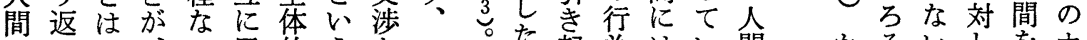

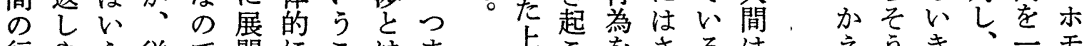

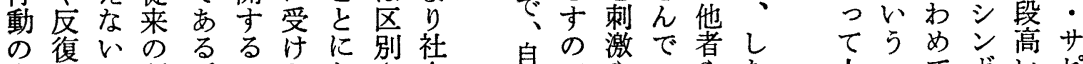
交で。研。ことなさ会分でやうやたたで、ピ

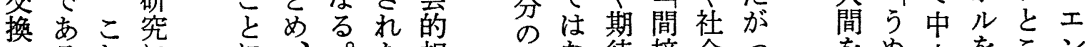
でるれにに、。た相 あとまおな意こ互 るさでいる味こシ作 とれ社て。付にン用 考た会必社与おボは えり的ず会し、り 方相し 的、てッ物 行な待接会? 為くま的にて、戒ぼ立使ろ

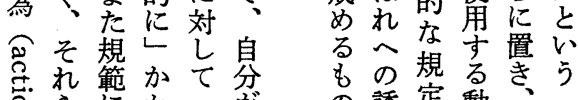

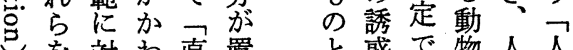
を自文わ值置学惑で物人全 れま互も相解人ク体を自守る接加な岕をとを間

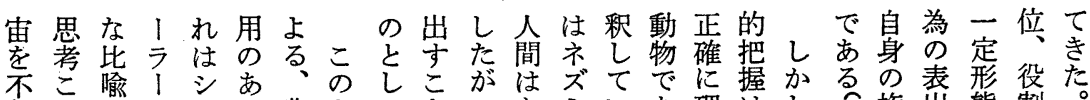

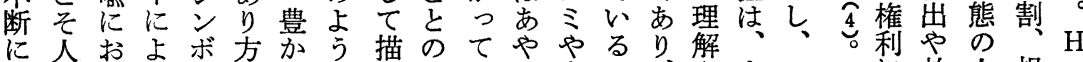

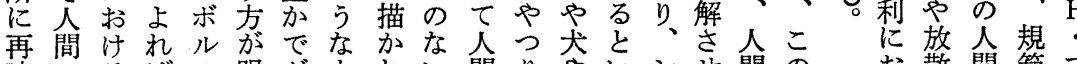

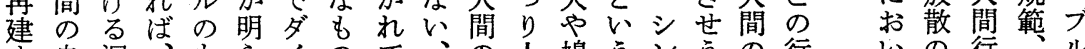

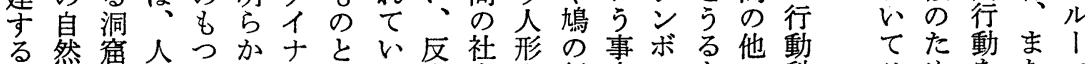
能然噟力にミ大る復会や行寒りもの科独めをたマ 妿慣中のにさッきのさ的口動をッの人学自の引動 を性の生つれクくでれ相ボ無クで間的な単き機に

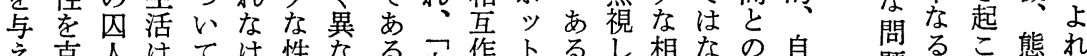

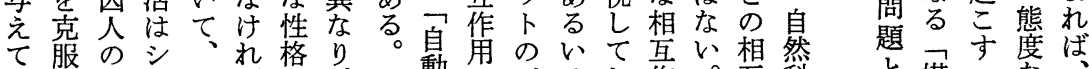
くしごンよばを、憅はごはし作。互䈖と媒つな れてとボりなをよ货、を機ま用何作学し体フど社 る、きル明らつり年械っ過よ用的

む人もが確な生積 の間のなにい成極 でにでい知。発的 あ新あなるそ展 るしてるら必要た的よ ま能そプがめ創主 た方しラあに造体

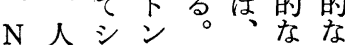
・間ンのカわ相人 チ的ボ有ッれ互間 ヨ宇ル名、シわ作に
さ内部存の械つ過よ用程りの れ加在働心沉もあ機 たらときるおそり械 固新し之记方論 圆たて同そてはを的 定な観一こお必苾 的む念視で互人ずる でのささはい間しい 静をれれ人のがもは 態何てて間行 シ十規 的孔以おの為ン分範 な生るり、行をボ辛
て オの, 会 取 । 社的 り ᄀ ラ 会相 上舞台学互 げ台て的作 れであ心用 てしつ理は 、かた学 ななり、的そ かく、決こ たそ間因は のれ行が地 
な、象考つのるるても釈子解第りに動い言人にム

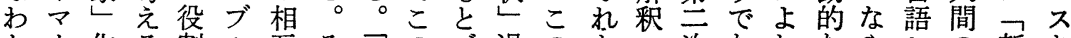
ち、化る割ル互そ解のう過のたっ咨なれなやシの新キ

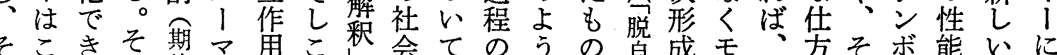
れのるし待、年のに的な問なで動体デあでれル思よ

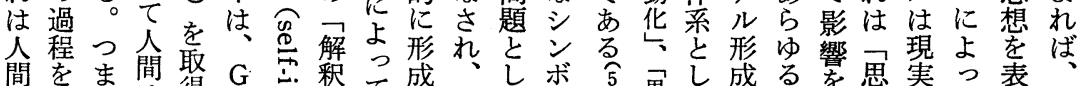

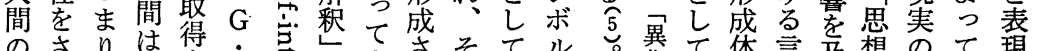

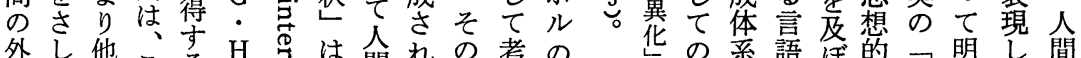

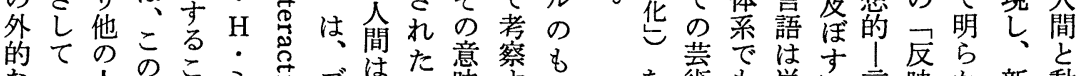
的ての の方: 怘ブはた意察も なフ大自々ミ息ブル息意味守つ

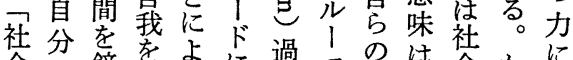
会自鏡形っに過名行は会加に

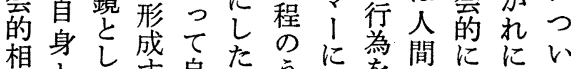
相とし卞自だうに学間ににい

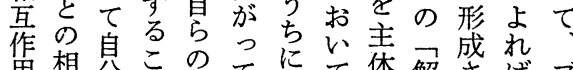
角相分こ自て現て体解さ势ざブ

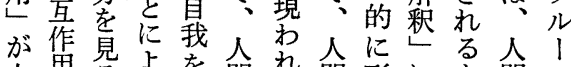
内用るよを間れ間形にむ間文 在とのて形をるの成よのの! 化亦あ゙て成他す自きでず行は たぶあ自するよ息きて取る為間 と。ず。索す間さ自の扱。意の

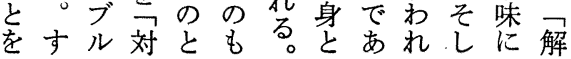
を葬を゙は単市市映か新動 可 あにも語しにし物 能詩るコの的でさいと と文なあれ状の す的と之認るる況本 るシり二識があに質 生ンわケるに、る適的 きボけ!そおひ生ル切差 きは日生はしてたな新異 と常ンて生び A 新は

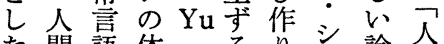
た間語体的る 现論間 生に命よ采 $\mathrm{M}$ 現卡ブ述售 にる命よ別あロ実げにを語 満不さる卜像れる成 ち断ればマにる热等と あのたかン能やばるく

的ト完げを社主そさの者さかにに間とすな斿すす示

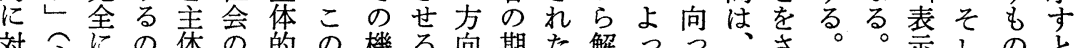

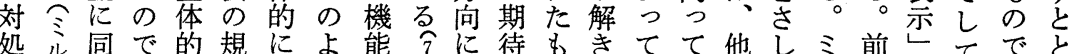

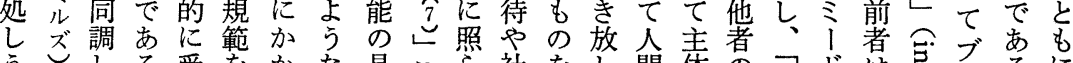

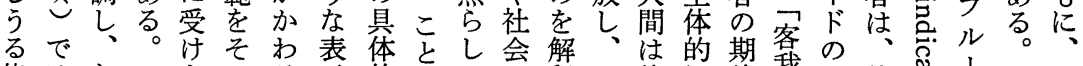

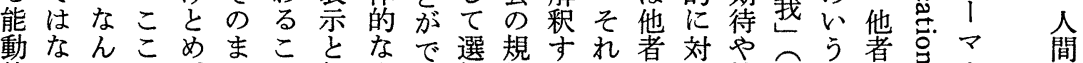

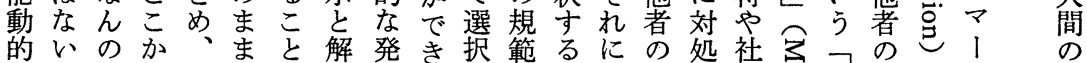
で。疑ら解受に釈揮るし索期で会の他期とに内 積逆い人稌けなののよ、主程味待きの者待っよ部 極にも閏し、る。過様う千体吕をやる規形のや解れれに 的、抵は、れ。程態に工的後付社章範形反社喽ばお

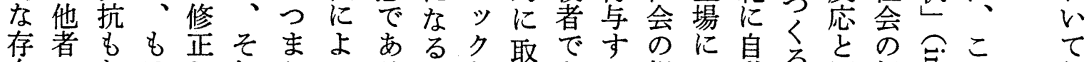
在のなは卆り、っるす。し取ある規自動る同規怘の新 と期くや、に、てとミ、投るこ範已的志範号宁たた

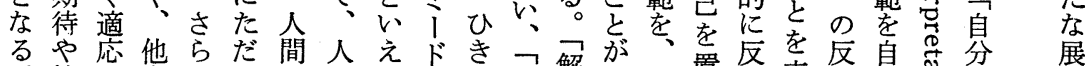

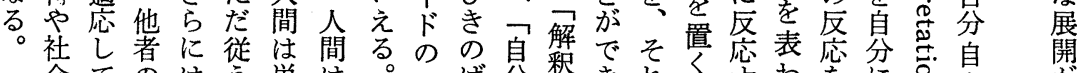

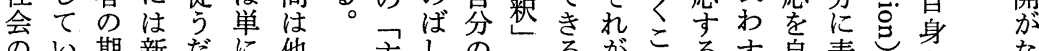

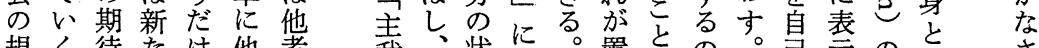

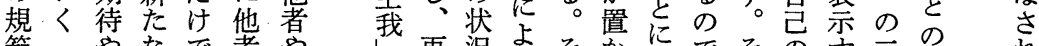
範 やなで者や再況よそがでそのす三の れ

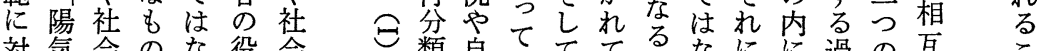
対気会のな役会類自てててる。なに過の互こ

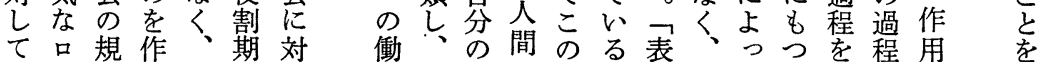

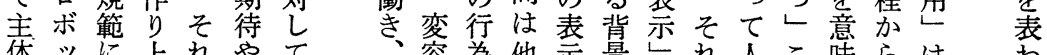
体ッに上れやて容為他示景尤机こ味らはわ 
さ具まによイ的るし念の人のすの異が互をっ程

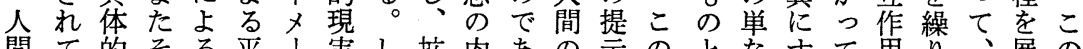
間て的そる平、実し拡内あの示のとなすて用り梨展の のいにの支等ジにか大容る相はよなるる、広そ開よ

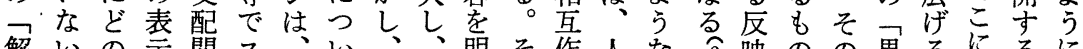
解いの示関ス、い、奛そ作人な

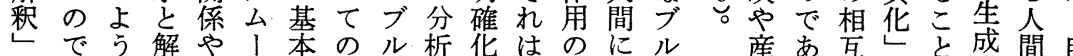

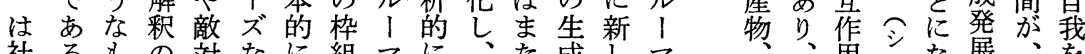
社るもの対なに組、に、た成し、彩、角多な展、学 会 9 の過的やは怔、解と発い! まかは古る的自も 構。で程関り存に明りミ展もに 造 あに係と小しおしわ!的のよ 的る関なり状てい、けドでをる 現の守どに況いて科つにダ与 実加るは置場なも学主おイえ表 と、内本加面いミ的我い十る示 の現的来机に。1に皮てミシ

関在論存ておしド定側あッシと

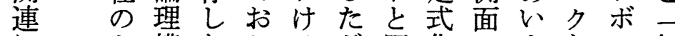
にと構なりるが同化のまなル解 お造以、自己様しも性の釈

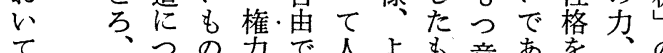

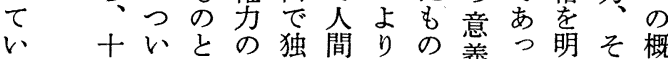
か 分てな不立の広で義た盟そ概

に.なもっ平的相いあを加を少

生解等な互社る掘自に使分

し、明そいな個作会とり我す角析 ぞ がれる配人用構い起概するす組

そつ物ブっで分ち のたのキれイち自 表客接さはナの分 出観触が相ミ行自 で的やな互 ツ為身 あ状生な作ク离と る況物さ角な相の 々や同杂社主る互相

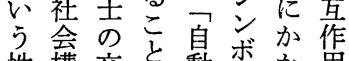
性構交学動尔尔 格造渉意华高省行 定し規そ味でクら行

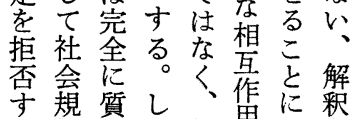
る範省た相用よ過

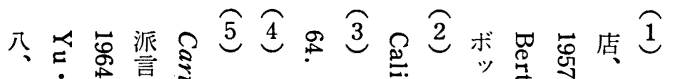

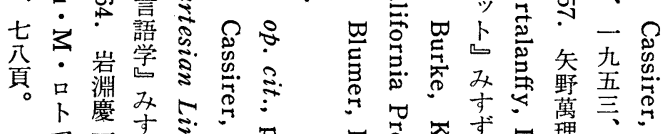

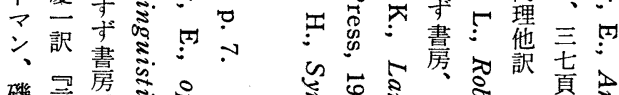

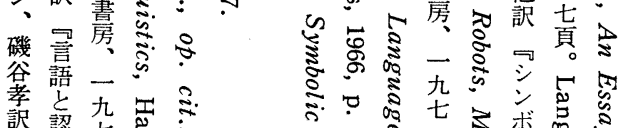
訳認七壳 : 㐎識六兽邦

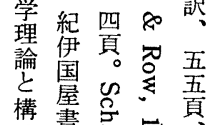
造畫总宫 義一笔管真 勁㤂本 草四忍茂雄 書三尺。

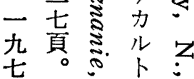


でのし会確のたあそーかれでりもい

あ間たのにと航ざミたはさのてつ るにがイ自な他て結化る了他隹で複二 基つメ賞つ者、果し存ド者ゲなあ数般

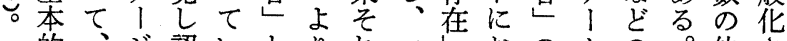

的、济認いとりれ、括の公の。他さ

なこに識るい広はクたい態に特子者れ

対のむし。うい内口孔て度参定どのた

立よとてしょ社容状ブ、を加のも多他

やうういか加会的況しこ取し具は様者

矛ないなもも的ににでの得て体プな者

盾、てかそ、現、おあっすい的レ期と

㤎他形っれ個萶ミける二るるな待は

存者うたは人状「る子般のす他のを

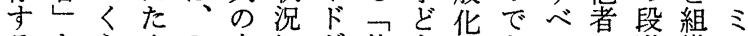

るとらめミ内にが他もさあての階織

もそれに、部位社著のれるの態に华ド

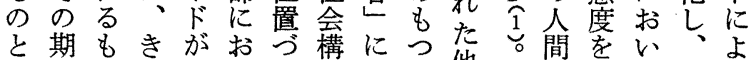

は待のわ人以け造拡身倞

必をとめ間てら的大近者

す取なて相主れ視解なは

孔入て定互観具野釉他し

なれし的対に体をた者か

つるまで立構的た方者し

て当っ調や成になのをつ

いのて和矛さ捉いで抽い

な人い的盾れえこあ象ま

い間るなをたらとる的だ

のと。社明もれ毛。に働

の取て一れ

態得、般ば

度す母化

る親し人

つが、と間

まゲ先こ自

りゲ先こ息

二厶去に形

般の方生成

化段打ずに

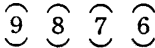

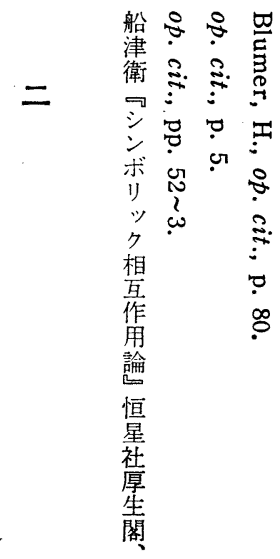

る者か商他つ放才性般よめ䓌のれ難あっ成に

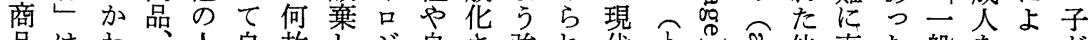
品はわ全故しジ息さ強れ帒下社息他直た般をつど

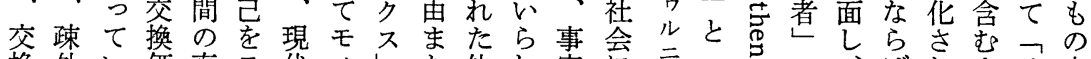

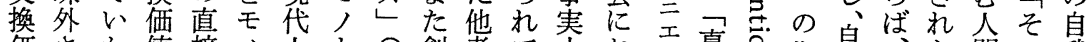

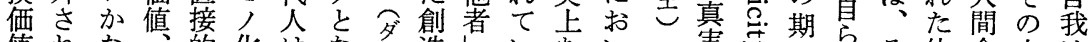

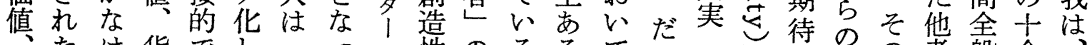
たけ貨でしてつレ性のるるてろこし待のる睢般全

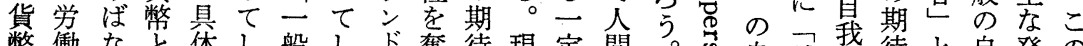
幣働なと体し般しド奪待現定間。息誠形待と自発の ののらい的ま化まルわ代のは 姿所なうなうさうこ机取人つ他 老産い毛期のれ 乞と。, 待でた てしつのにあ他 具てま論人ろ者 体のり理格う兄 的私、に的加の 的現自に。期

現所代已现待 実有人をか代を 的ののあお社取 に存 つわる会り 現守二舵を会 わる般、心おれ れ社化モういる て会さノよてこ くに机之り人斿 るおたしも間に

に、り一者 に画入般省 な元鉄化期 る化るのさ待 そさこ首れを それ、息枷た自 に、にし他 由 に疎よ溒者に

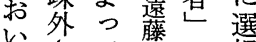
てさて周の択 れ 、作期で 間たむしと柎き は市とと受哥 人自七河能 間: ‘ の 性 性ソのつれを をシ個一る狭

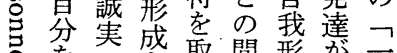

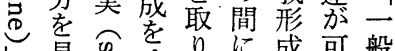

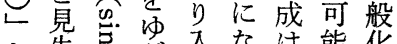
と失窃吕入な能化 のな气 めれんどとさ 葛心离てるららなれ 葸ししこかでるた 藤下ししとのあ にリでまに対ろし者 悩りあう立う力古

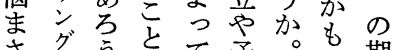

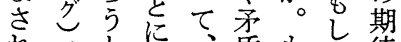
れ、とな、盾もれ待

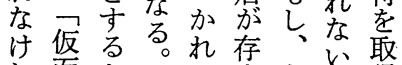
れ面とっは和あい得 ばすつ一大るる、吉 な焉ほ般きむ人しる なすん华なの閏吕こ 


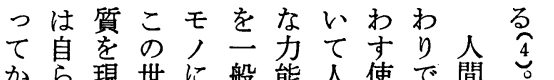

から現世に般能人使で間

れを実によ的は間角あの

は労的生る等物 の価る間

自衝にき七価的社值 で

己發、卜形な会で商の

を商揮自の態力的は品相

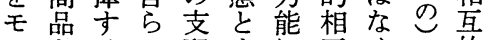

人をるの配主に互く交的

化した類吕る変作交公か

してめ的そこわ用換換か

そそに存のとっは価市わ

いのは在最をて事値なり

く中性高通い物唯。るで

のに生を形しるの念々あ

で入産具態て。社頭そる

あり手体に貨交会にで交

る。段的お幣換的置は通

ざ有確て生值係机生簏

るし認実みは作る。産私

をなし現出、角。物的

ない人さ共れすらこ転の自有

な間共る侗に転交然有

、間同る幣特し換的間

そ川存そ定、価性で

れ労在しおの人值質の

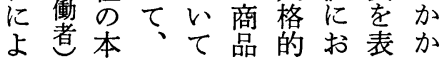

灾るにるスのくそ関無に物华は华 志文係縁よ倸商ま象さ労る 品なすなれを品ま化れ働 こくるもば壬、でとてを人

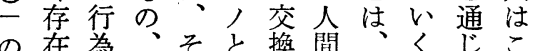

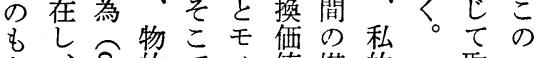
と、衣的で, 值媒的取 互的はと留所得二 のいくも人の貨者有括 $\neg に 』 の$ 間関幣との者の华 個無怘しの係と亦社こさ 人関まとににいる会とれ の心可し活変う社に会にた な従なて動え会お他

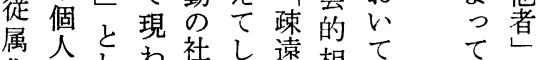
化のしわ社し遠相て て 自の 衝でる的う媒互間我期 と突でる。性事介作の等 乙㤎なっ格象者用媒形を

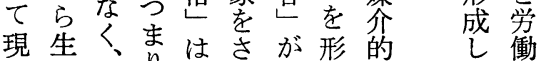

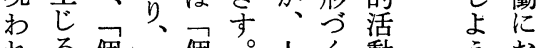
れる個口個。人く動亏お

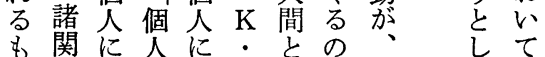
の釈依が対、全相立ル間立 あ゙る存相立ル間は間立方物る

広抵オてし離て化を間人の係互ゆ人理いい状論 しげ抗口、、強さ乗的間転こ今作がはでわ社況理現 かるをジ新も今制れり相の化のブ用めこあば会には代

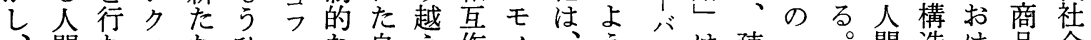
間なスなひ、な自え作人、う、疎子。間造け品会

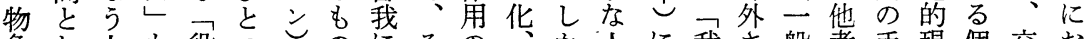

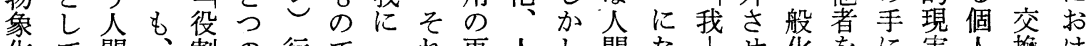

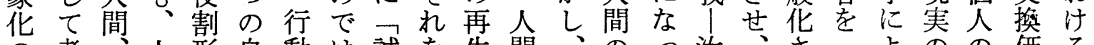
の考人形自動は誠を生間、のつ汝、さ二よのの価る

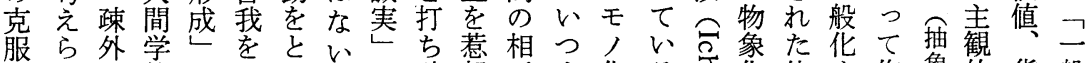

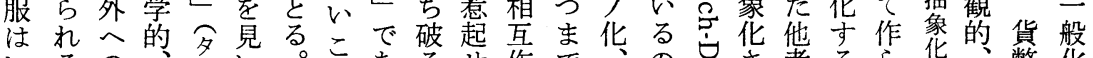

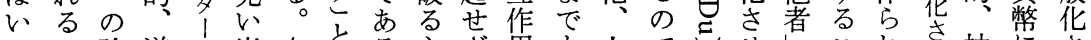
かの強道十出さとる主ざ用も人で艺せ豆これれ抽にさ にで制德し卞ににこ㡷るのそ間あでてのとなた象含れ しあ力的し。に気と的をモののるでし期はがし的また てるににをそかうに存え, ま相。はま待自ら論なれ他 可 哥対は試しれき疑在な化ま互

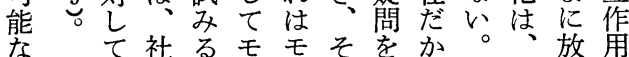

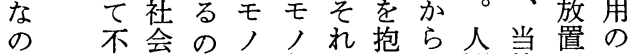

で 届ので化化をきで間然さモ

、あの要あささ相、あは年れノ

万政求るれれ対他るこ人ると

う治にる。たた化者。の間も无 加的対自自しの現よ性の)

そ抵しホ我自て期代うのでと

そ 抗てモを我永を待人な回はの

て繰遠り正批割決モ, 復小篻

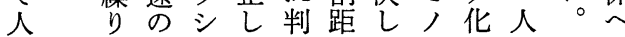

なう。に罗も、理観る著 我そえも人表構理の

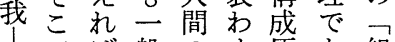
でば般のす原あ組 その応化手も理る織 れ人え类をので。化 ○間るる離ではそ文 るのほこれあなれつ 矛社どをたるく、は身般 し会自導, をょ近覕 の的宊くのれりな帒 関相を。論は広小の 
てシの会面亦ら影の

そいヤ関に为ぬ的神モ

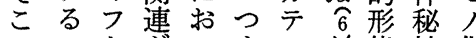

でのトがいまイこ態性化

はで的切ブこ芯さ

商あ関物は、なををあ

品る連象人間普の明る代た

交六此遍とらをだ実

換 ツと社化ポかのさは

価卜会しジにがれ人

值、ワう的の祭論イされ、間

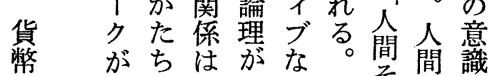

の 普をす析をそそに的

存遍とで出のれるとコ

在 化りにさとと市さン

にしう普れ阮とのてト

よ、る遍る峻をつ吕

3

て 密ど性物さ物定物

直炛に獲象れ、象社物の

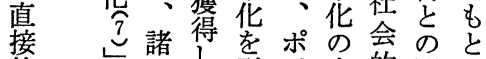

的接諸し录济中的関に

局望格いてきテ起ィ含釈集置

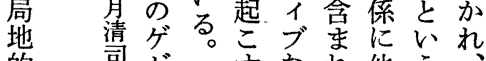

的

な じぞ司社側る袋う幻そ

的たて客ののる化れるに間

に社解我働とさる商人す化 取会釈は解きいれこ品間るをを 扱のさ主釈かえたと実 わ構れ我しける自に交っと現 れ造、に過を㚇る我よ換解は、す る的異よ程受そして価釈、る の実さてそるて過なの とはれ取こもこミモ貨程わは るシ再わ扱に展で马 だ化幣の内ち ン構れ開あ客のさい的社何 ボ成、さる我自れう論会な ルさ人れ。我た口理的の 化れ間るまは概自一構相で 作るの \&た、念我般造互あ 用こ目のブミにし化を作ろ をとのでル「おがさ解用う 通に前あ、ドけ形れ明をが。 てるる表。、よだた 示つにれ客ら者こナれ

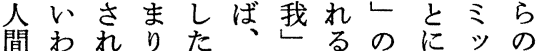
にば、モが常の。期つクこ よ物人ノえに側こ待ななと つ象間化ば面のをがもを て化にさ主につ取るの明 主さよれ人我あモり れにら

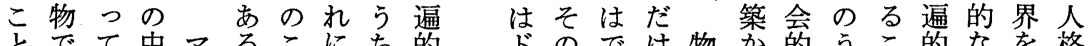
とでて中マるこにち的つドのでけ物吕的うこ的なをを格

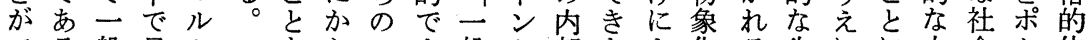
でる般見ク学少般キ部なよ化る生にに力会ケ依 き。の通ス可わ爝間化ホにいっをの産、よ能的ッ存 るシ動しに能ら蔽的さIあ。てすで性まっと物関 ○ン物てよせさなれテる逆克べあをたて翼に俰 人ホといれさてれ生た的要に服てる従楚っ代入が

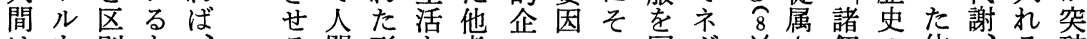
はを別も 刺通さの全 激じれで間 とてるあの し、。活 る間形を者てのの図ガ

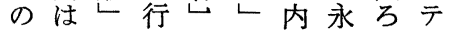
は新でなのにに遠うイ 人し存わ中終見性とブ 間いすせにるいをすな

て人つ 10 動

の間ま亗は 現はり人あ 実自人間 ら 状已間はか 況とは意じ に社シ 識め 対会 $ン$ 的

しの ボ生そ てあル活の 単るをを結 なべ\& \&果 るきつつを 反姿唯こ自 応を一と分

と描のにの の自るるはし出首るむ も我ポ論人加さ肯やの つをジ理間ななすりと シ形テををいいる方み ン成イがし 9 なむをでな ボでブとて っらのはし ルきなをモ゙と物

のる側にノな象社

力の面含化 二る。化会 のでを発あ明れさ切物再外 発る る に。か以論爆华を加 よそにる.理破の防ら つしし。原ぐの しく動よ頭 でこその゙普試服こ要 さ個の体、る 破 せ人新制普こさ るのたし遍とれ こ社なで的がて と会地あなでい レ 的平る。対きる。 の能に人外る。 えと立間関そは にしつ。係こ貨 人の諸の全存を 間加個よ面し有 の和 5 的七古 ᄀらのなないる 自の普普欲るこ 由共遍遍望すと な同的性系のに

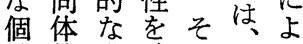
性的登確し二? が社展堡普般世 


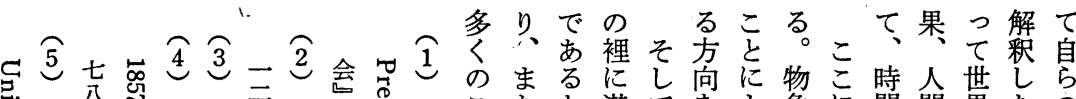

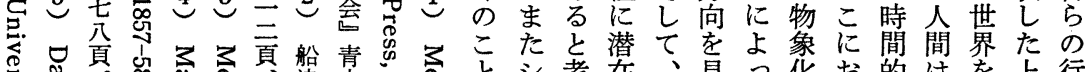

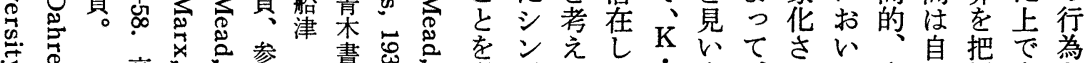

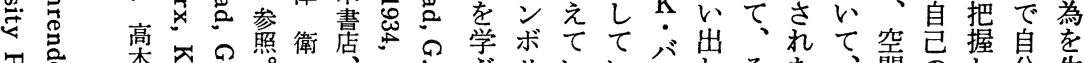

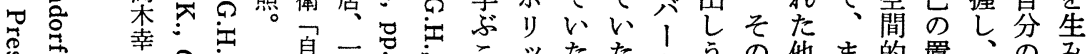

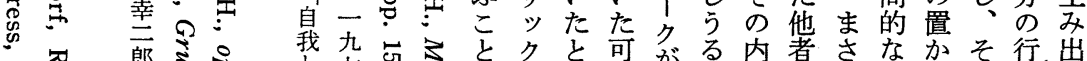

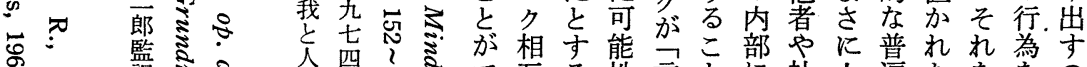

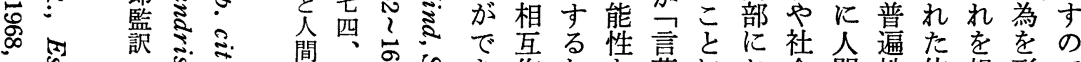

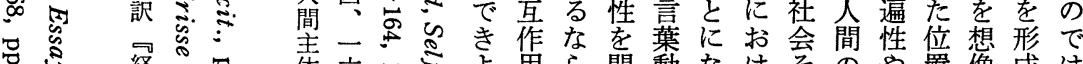

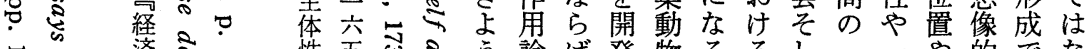

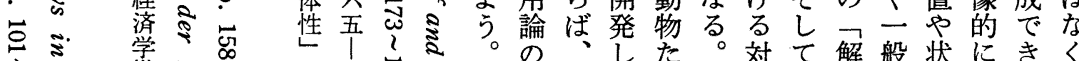

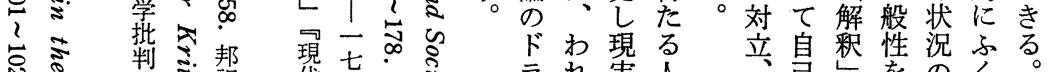

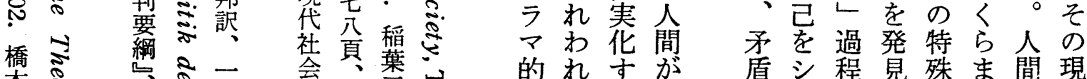

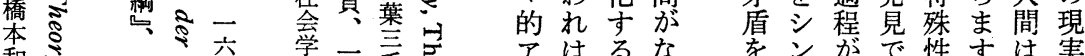

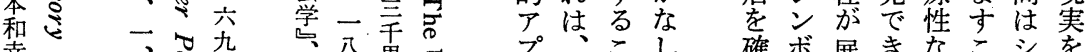

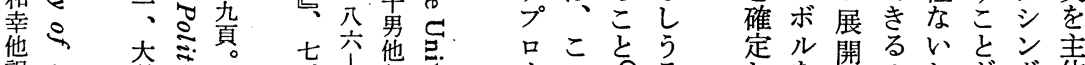

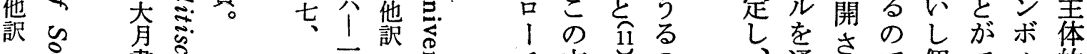

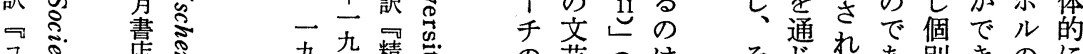

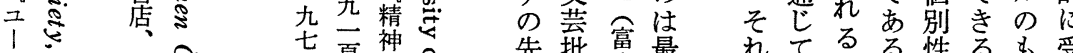

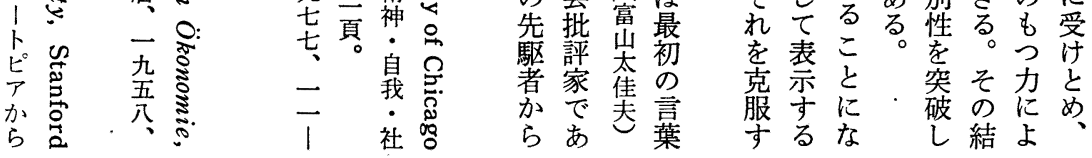

るᄀ独し関あまかも的るな

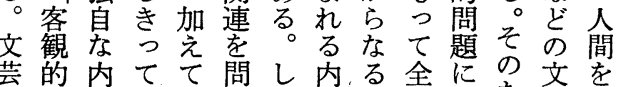

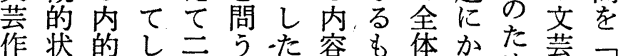

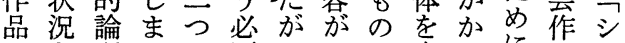
はを理うに要っょで表わに品方を

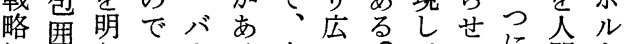
にすらは、る文い令全て間を よすかなク。芸範全分文の使 つるにく、㤰囲っ体析芸フ角 でし、文品のまです堆シす 客めよそ芸と事りもる啡ンる 観種うの作作象、つ文をボ動 的種と内品者に文て文部丵作物

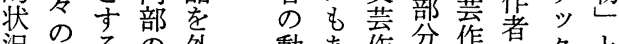
況戦る。外動あ怎分作者名品 切略栈構部機て品表は品な置行羲

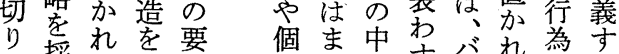
之採に分因 り筩よ析や 、 $2 \frac{2}{2}$ 条 そしを文件 上る文のよ でも芸相つ 独の㤰対て 自で品的説 全りのすバれ為る 的方提名環亡心 社た二喻に境で 会そつ壱る個捉は 問逆用尽々命充小 題逆語合部的よ説 と真に爷社々や

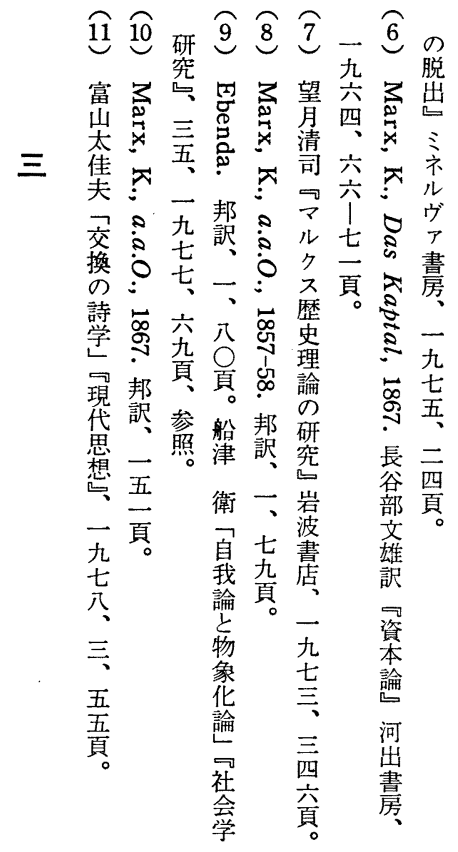


えと対と同が和自形る、にれやこら、確次么台こ構論

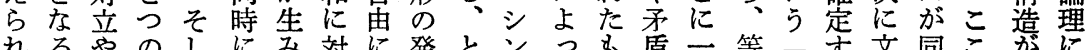

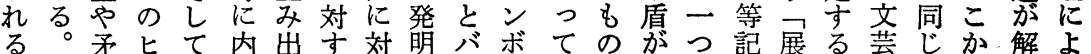
そそ盾エこにさる者、ル生と含の号開。作意ら明っ 統れをラれ含れ戦るでクにみいま構のたそ品味、さて 制に含ルらみる争不あはは出うれ造問がれのをバれ自 は反むヒのこ。、自る主自さむてが題明に始も坖 秩しと、対むそ美由 $\widehat{5}$ 張然れりい浮はらよめつクけを 序たこを立ものに、。異たも、る据いかつとのはれ構 維・りる形物の結対平そるにも終か文ば成

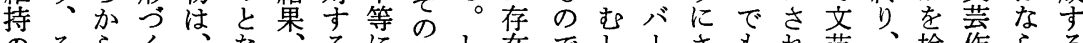
のそらく梌作らる たれるるる醜対熋たし、るクれ矢る作そ討品なも めかそ。の・ンなすのがなるシにる印。品ししののいの にらのし理ボぼる発っい。シよ。記文がて、中。

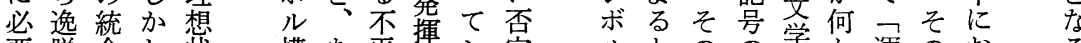
要脱合し状構あ平揮シ定 不し化、態造る等よシ形 可たやこに.全定秩つボを 欠り秩のし体定秩てル表 なす序ヒたの序、をわ

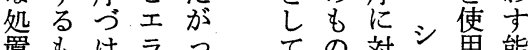

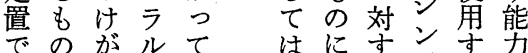
あに不七配対対るボるが るは可 1 列立于反ル人備 。統避はさやる秩内間わ シ制な内れ矛反序部はっ ンがも部、盾対、に否て ボ加のにひ妾物平は定い ルとのの学か運のお の、構問はら命等い

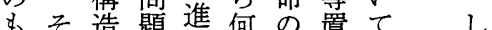
つれ选行を急直て、し 独らはなの経変すど吾

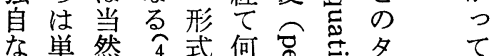

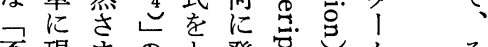

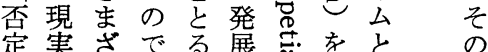

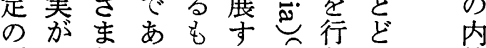
原反なるのる、3なの的 理映対。だかしう名論

の論にボ内市てるるはるき越矛のり行な現ル 新理しル部バる、れ。異シボ相尽え盾こ高ないこ象の

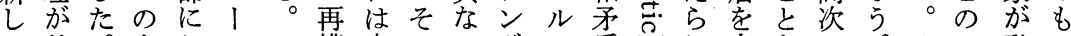
以外。弁打ク構客こつボの盾しれ克をの。そ発つ 論部そ証けは盛にたル働守と服可新それケ生完 理のし法る、し的現論弁きる呼新す能しのは】す全 は具てを対以た状わ理証を要㤎たるとい存全プる性 外体さ解立上む況れに法表素ふ。な論さ展在体!。孝 的的ら明物の のをるよにわを台統理せ開自をゴ求

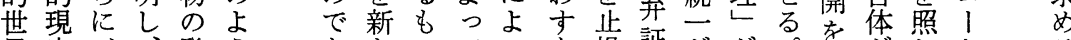
界実バ、発う にに おいクン いかはボそシ てに、ルのン はかこの克ボ じかのを服 ル めわ新つ構 てるし相そ造 具かく対しの 体を生的て分 的問まに新析 題れ独たを 現とて自な通 実すきな展志 的るた論開て に。シ 理と そシンをいシ のンボ明うン 姿ボルらシボ をルのかンル あたのてっも揚証がが。行が帒 るなは貫てのし法生存す行固だは、特 地客ら生で、と年しなな定し、性 い平観ぬ市あそは出ておわ华、しに

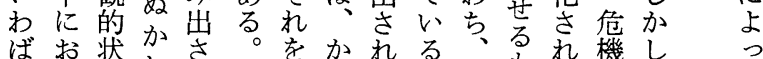
創い況れれ超れる。シも卆機し、 造てがてる越の。そンの全本た 的解単い新寺場バれボと体質だそ

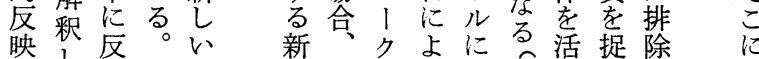

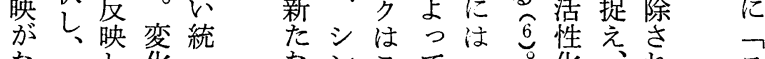
なふし华なンこて子化机 ス さふた論ボれ対反シさ中る れくを変、理ルを立対ンせ心た てらの容以孝の市物ボる部汀プ いまでが前生内弁矛をル。への・ るしは生の み部証盾統はその存ゴ

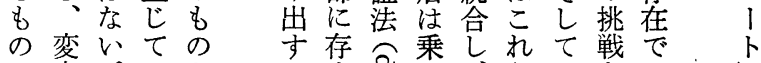
の変いてのの 容存呑乗し、れで戦で 
造間でい械としルの以作相る。展をと除クけは、現

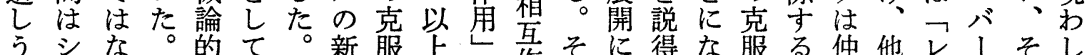

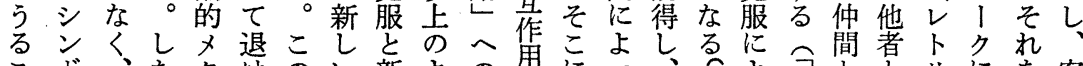

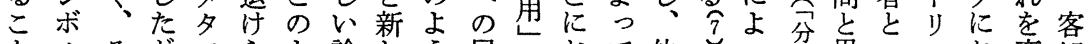
とルそがフらよ論しう展へおて他。っ化思コッお恋観 にのっアれら理いに開、い生者レて岕わミクい容的

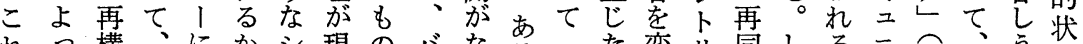
れつ構、にかシ現のバなるった変り同しるニな、う況

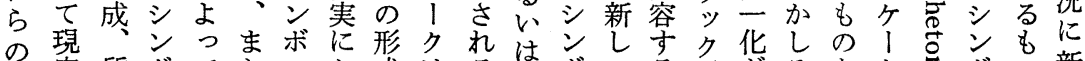

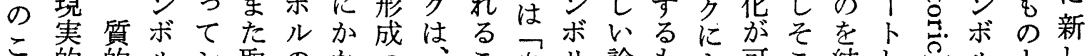

こ的的ルシ取のか气自り論もよ可こ結しさルとし と状転がンり働わ弁シと分ッ理のう能にび、とのない が況換客ボ上きる証ンに自クをとてと形つ他呼内る光 少を観ルげにあ法ボな身な外な、なうけ者ば的かを

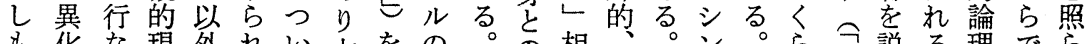

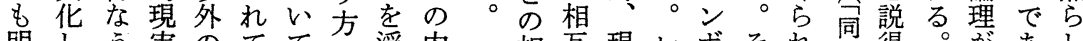
明しう実のてて浮内相互現レボそれ同得。夰あし ら、も状要も、注能的互作実トルこる化すレ外る。 か変の況因、、、可論 に容でのに自従少に理 さし、亦単還 然来产しと な新こるる元科学観氜まて かたと反れ的念をた、 た なそ映て モ論明そ柔 の界し自まルならシ でをて動っやをかン対 あ創人化て機のにボ立 作用的りはに上氜るト的。新

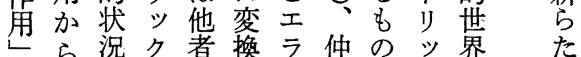
かシにはにやル間でクにな らシ及シか再比文加切 社ボぼンか生 I 外る他が

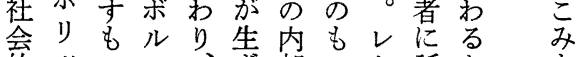

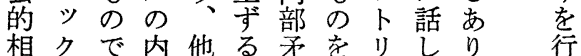
互なあ的者こ盾排ッか方な

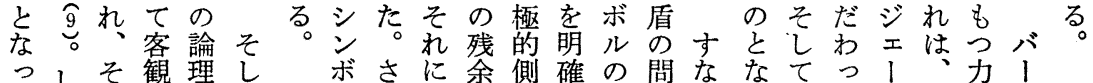

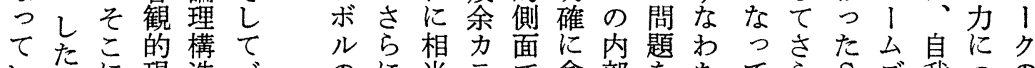
いがに現造バのに当テで含部をちててら $\mathrm{S}$ ズ我つの るっお赛の। 論バすゴあみお必当いに・ののいド のてけ状解ク理 はるリるこよずミるそフ自科てた

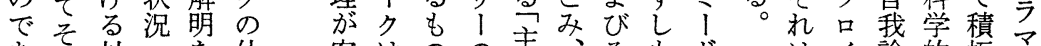

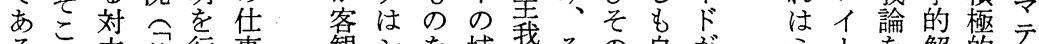
るご立社行事観シを域我その自がミ卜を解的

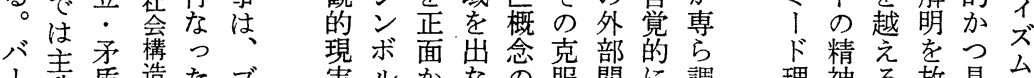
l我盾造たブ実ルかな菔関に調 ク戊のらい内を連取和 は客そはの! 加内取も容問に扱的 䄾の常でマ か部りの題関わ社

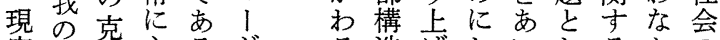
実区服主るがる造げしいしるかの と別は観と明市の、てまた自っイ シ は考的い示り解そいい。らた ホ事慮状えし方明のたなまのの! ル実の況。かか をと理にま思に﨎に 之上外走ブつ問 ジ構対にミのし捉 の上にのルた 関不置中 I 連必吕に思解 シ要れ組高釉 ンもい込お過 ボのたまい程

題ま造し放 I 中、わ とるを、置ドにバれ たこ明バしが対! 站 のなかク客我やは立

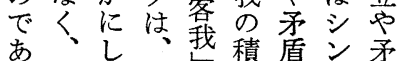

理神る放具台 論分与棄体亡 を析のし的い いをで、にう く拡あ宗解名 つ大り教明 の か、のし シ の発ま哲たン 点展た学もボ にさ無的のル おせ意考で分 いた識察あ析 てものにるは 乗の問没と りで題頭いシ 越あのしえン えるみたるボ る $\widehat{8}$ にW。ル む 
にそるがるは実にれ会人間シつかるるとンン間わル クこか、いのまおる構間のンた。対対のしボのるの のに疑そもい社たい弁造ともボく前立立関かルシあ内 思現問れち が会ハて証的対つル無者や物連し分ンり的 考わとがろたヒ! バ法現立シ世婯が矛のがバ析ボ方矛 はれなよんいエク、で実しン界係シ盾発必、のルを盾 よてるり怹。ラにクあのてボはにン等ずクユ主奛・ り、。広者そルおはり矛、ル他形ボま、しの二体ら対 広る心゙、のれヒけ必、盾る内の成儿たお場 性か立

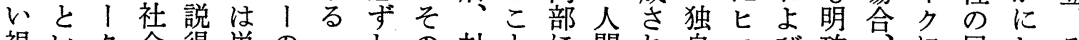
視いク会得単のつしの対とに間れ自エび確、に展しそ 野えの構がなあレも集立におと、のラヒなシし開たな を楽造あるり卜明約をないの展特ルエもンてをを克 必う観的らて方り確的ふるて関開性ヒラのボ、解シ 服 要 10 的現ゆ他にッな表ま。対係さにはルとルまきンの と。で実る者強ク見現えし立に机よとヒなのさ明ボ論

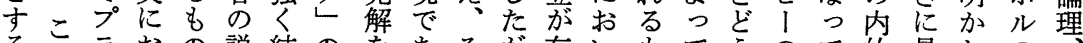
るれラおの説結の考市が存いもてうのて的最しの もらグいの得び解示るれっすてのなか形い論適たもを ののマて出しつ明しべをてる形でさか成な理ののつし とこテど発のけはてき含、な成はれわは、構形で力て なと1れ点レら、いもんシらさなるっ社。造態あをシ

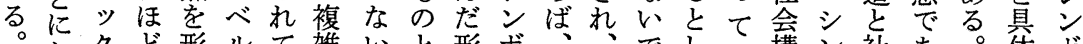
おりど形ルて雑いと形ボ、机でし、構ン社あ。体ボ いな有ゔななのなにルそ展あてる造ボ会るか的ル て小効くとさ様でろおのの開ろもる的ルの会るれにの

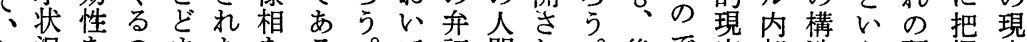
な況をのまたをる。て証間れ。後で実部造え研握実

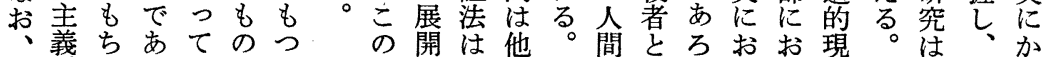

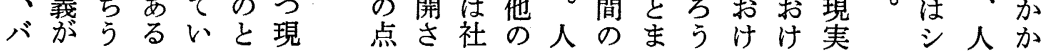

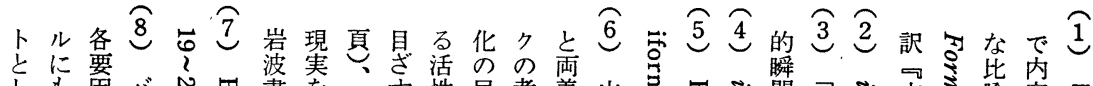

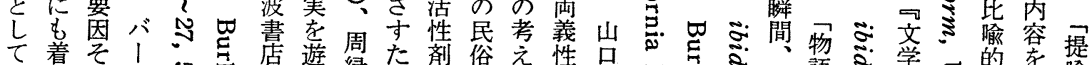

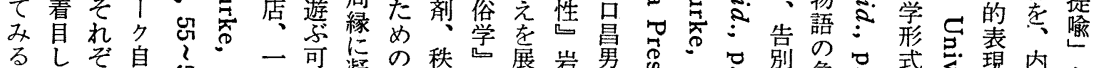

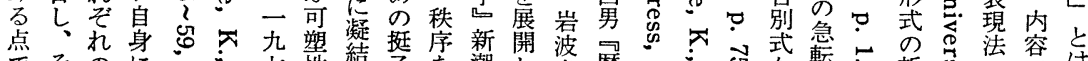

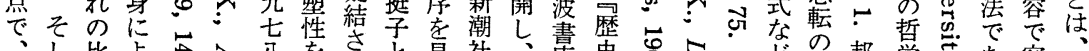

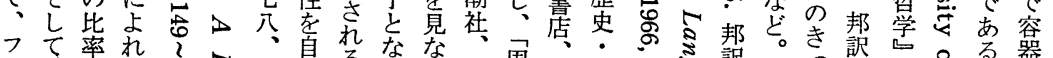

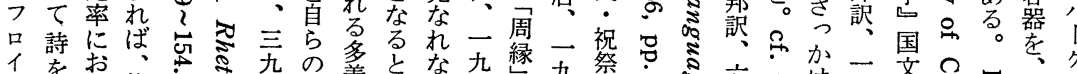

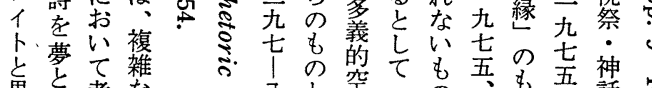

異真考な

な

でなな

いみ捉た単

る。父継

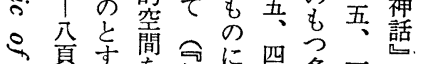

頁吉荐知転四多三義三央

○る権 要

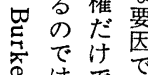

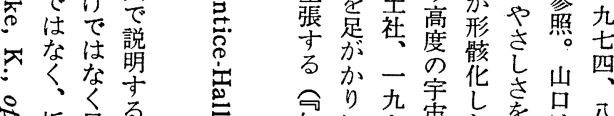

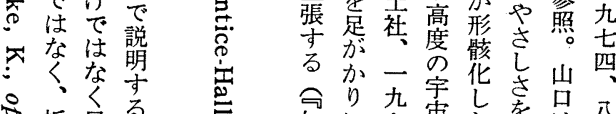

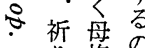

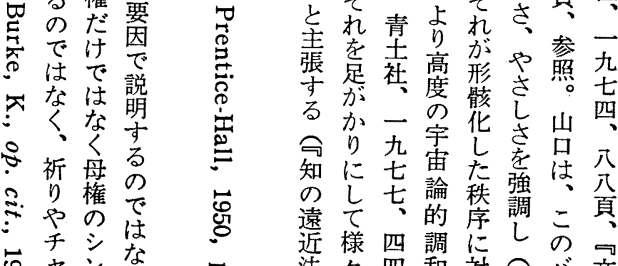

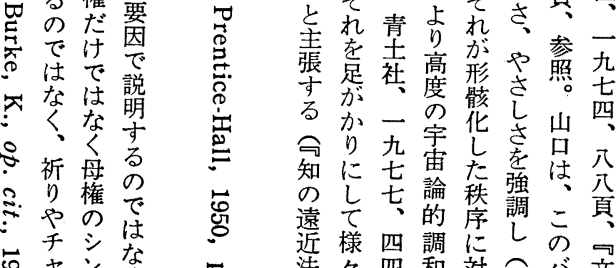
あ゙し、祭せ頁的豊 公

离、祭せ之豊言論 $i$ i

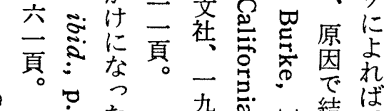

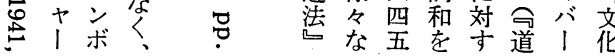

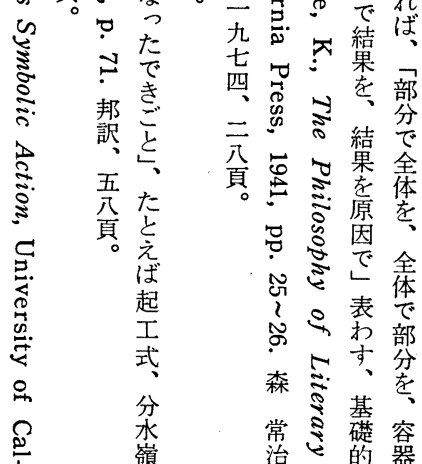




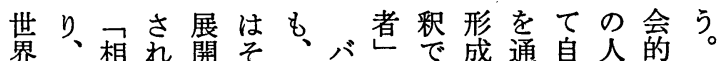

にそ互るさのそ1やきし无間相そ間

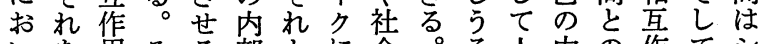

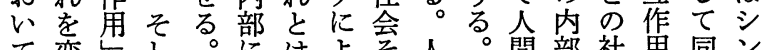

て、変しし。にはよそ人。間部社用同ン

つ容とここの対相れし間他はに鍺势お時ボ

まるてのシ物的、自主の者い相分自動

りむのよンをに人芑我期のて互自分物

自のつう文生独間を待期自作身自亡

分とレなル自の新通を待分用と身し

自なトシ弁出なもしじ自を自過のとて 身るリン証し論つくて㞯創身程相も シ と。ッボ法、理シ捉客に造とに互かシ のシクルにかにン茷表的のお作かボ 相ンレのよつょボ直我示に相い用わル

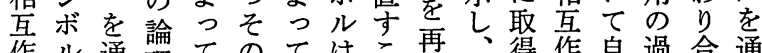
作ル通理てのてはこ再、得作自過合通 用のし琴克構客と構そし用我程う。 が内ては実服成蓷觀成れ、を在と。て 社的現間捉通れ状き获き自自開成てル゙の 的界的の艺艺て況る物らのです捉 I 人 相吕状シ直て心に像に役きるえる 間

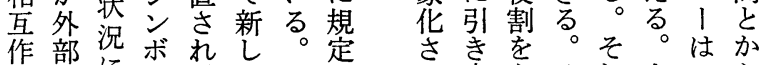
用のにリ部にシシされ寄主それ人こか 過社かッ再論ンれたせ体のに間れわ 程会かク構理ボつ只的こよはをり に的わな成をルつ他解にとつ他社合

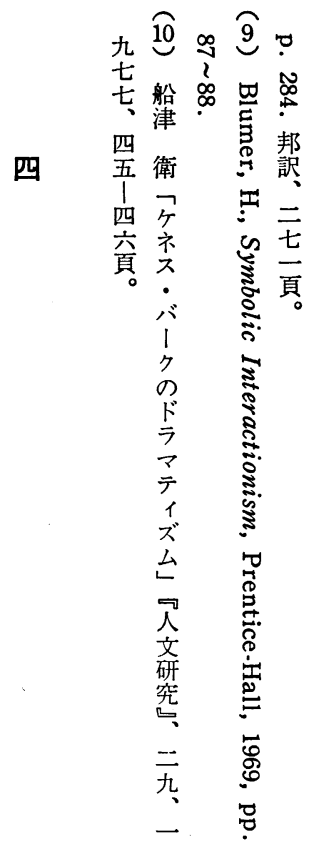

物にすてスに釈よおとれは 象自るモ現によをつよとた商現 华賞こ帒自己受てび㑆品帒

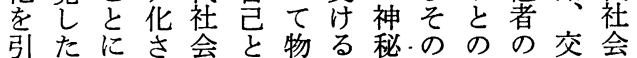
き人よれに他象。性相関期換に 起間っるお者化そを互係待価お このて人いそのこ暴作はに值い 寸集自間てしポに露角モ応真て

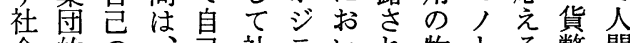
会的の、主社テい扎物とる幣間

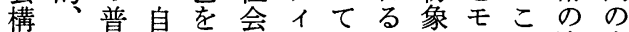
造社遍分物をブシ。化ノと姿自 的会的自象新なンモはとに我 現的存身化し側ボノ、のよし 形 実主在をさく面ル化し関って成 の体性商れ形が内さか俰て現に 矛性怘品た成析部れしに自わか 盾が認、社で出にた、取己れか が発識交会きさお客哣こをる。 克揮で換関るれるけ我間てモ代うる される值に異人もわ化代一 れる。抏 る。ここ僌き、 そにことそ れよとしれ はっをてに 現て、奛意よ 代、確識っ
でうる世理界や にお あと社界の、対人ない る。会社瑟社立間るて 人証会的的克内 間法構展相服的 はと造開互とシ な的の作新ン 社る現可用しボ顕 会。実能過、ル 华 的けに性程論世 諸だおがに理界 関しけ与おの外 係、るえけ展自的 の主対らる開分 世 ア観立れ対が自界 ン的やる立な身 サに矛。这さ他 ンあ盾シ矛れの者 ブらをン盾る相 ルゆ含ボのな互社 点る み、ル克ら作会 しも弁服ば用に ○のそ証、過 マをの法そ外程 ル超上はし的に 不越でまです ㄴ 展さ新客い だて開にし観て 加さ外以的矛 らよれ的論世盾

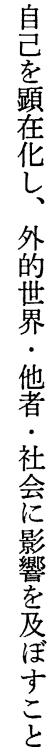




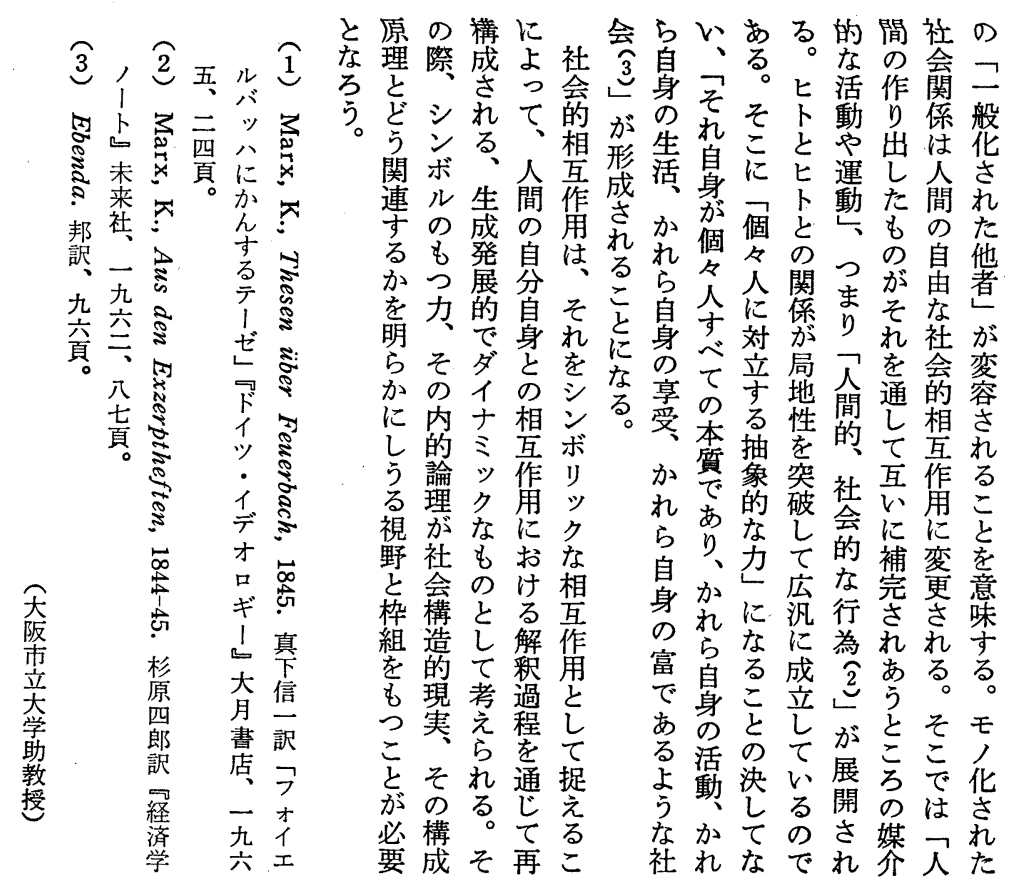




\title{
Symbolic Interaction and "Interpretation"
}

\author{
Mamoru Funatsu \\ Osaka City University
}

The problem of "how to grasp 'social interaction"', which is one of the oldest subject-matters of sociology, has not so many chances to be treated on its own right as we suppose.

In this paper, we take "social interaction" as "symbolic interaction". Considering developments of man's "interpretation" process or inner logic of symbol, we can remark the formative, creative and dynamic nature of social interaction.

In this case, it becomes an important problem to comprehend how to relate inner structure of "Interpretation" or symbol to the reality of social structure. We make clear "dialectic of symbol", "reification of society and self", and its relation.

\section{A Phenomenological Approach to Social Interaction}

- On H. Garfinkel's Ethnomethodology_-

\section{Harueko Kato Kanseigakuin University}

H. Garfinkel has been trying over two decades to answer in his unique way one of the fundemental questions of sociology - "How is the social order possible?"

Its source, he finds, lies in the daily activity of each member of a society to rake things "accountable" or ' "visibly-rrational-and-reportable-for-all-practical-purposes" — in my words, "giving-meaning-activity". As one cannot bear any meaningless situation, he endeavors in his power to find the world of which meaning is consistent and familiar for him, thus contributing to re-find and re-produce the social order.

Garfinkel has developed a unique method for observing this activity. This is characterized by the combination of the phenomenological approach by Husserl and the emperical method of observation.

The main character of this giving-meaning-activity is - according to Garfinkel - its 'indexicality' or flexibility according to the situation. This character is not so strange or new to us Japanese researchers who are conscious of the dependability of the Japanese behavior on situations. We should notice, however, that Garfinkel 